\title{
The Influence of Discovery Learning Model and Mastering Vocabulary in Environmental Sector to the Writing Text
}

\author{
Yosi Pratiwi ${ }^{1}$, Harris Effendi Thahar ${ }^{2}$, Irfani Basri ${ }^{3}$ \\ ${ }^{123}$ Universitas Negeri Padang, Padang - Indonesia, (yosipratiwi@yahoo.com)
}

\begin{abstract}
This research aimed to describe the influence of discovery learning model and mastering vocabulary in environmental sector to the writing text report observation result of the students of class VII SMP N 31 Padang. The type of this research is quantitative with $2 \times 2$ factorial experimental design, the study population amounted to 248 students.Sampling is done by purposive sampling. Data collection uses two instruments, namely objective tests and performance tests. Analyzing and discussing the data descriptively with the concept of experimental research. The result of this research can be concluded that, result of skill of writing text report observation result of student having vocabulary mastery of environmental field is highest and lower, who were taught using a higher discovery learning model than students taught using conventional learning models. Furthermore, there is no interaction between model (discovery learning and conventional) with creativity (high and low) in influencing the skill of writing the text of the observation report of the students of class VII SMP Negeri 31 Padang.
\end{abstract}

Keywords: The influence, writing text report observation result, discovery learning, mastering vocabulary, environmental sector.

\section{Introduction}

Indonesian language and literature learning is inseparable from the four language skills, namely: listening skills, speaking skills, reading skills, and writing skills. An important aspect of language skills taught in schools is writing skills. In learning writing skills, students are expected to communicate in writing. In addition, students are expected to not only be able to understand the information delivered directly, but also be able to understand the information submitted indirectly. Writing skills is one of the language skills that can convey one's aspirations or thoughts in writing, because writing learning requires aspirations and imagination.

Meanwhile, according to research of Programe For International Student Assessment (PISA) mentioned, literasi culture of Indonesian society in the second worst year 2012 from 65 countries studied, in the world of Indonesia country ranks 64 of 65 countries. That is, the writing skills of Indonesian students are still low. Based on the International Institute's survey that the literacy culture of Indonesian society is far behind with other countries in the world. Literacy culture is a reading and 
writing activity before carrying out the learning, literacy as the heart of the students' ability to learn and succeed in school also in facing the challenges of the 21st century (Republika co.id. 25/12/16).

Previous research on the use of discovery learning model has been done by Oktaviani (2015: 1). The results of his research indicate that the use of discovery learning model is effective in writing exposition text writing because there is an increase of learning result of expository text writing and critical thinking of learners in following learning using discovery learning model. Vocabulary is the words in a language used to communicate. Chaer $(2007 ; 6)$

Discovery learning model is expected to realize the competence of students to be better, especially in learning to write text reports of observations. In addition, the reason researchers chose SMP Negeri 31 Padang as the object of research is also caused by research on the influence of the model discovery learning and vocabulary mastery of the environment on the skills of writing text reports of observations have not been done in the school. Researchers want to know whether there is a significant influence the use of discovery learning model and vocabulary mastery of the environment field to the skills of writing text reports of observations of students of class VII SMP Negeri 31 Padang through research entitled "Influence of Model Discovery Learning and Mastery of Vocabulary of Environmental Field of Text Writing Skills Observation Report of Students of Class VII of SMP Negeri 31 Padang ".

\section{Method}

The type of this research is quantitative research. Sugiyono (2006: 86) explains that the method of quantitative research can be interpreted as a research method based on the philosophy of positivism, used to examine the population or a particular sample, sampling techniques are generally done by purposive sampling, data collection using research instruments, quantitative / statistical in order to test the hypothesis that has been applied. The design used in this research is factorial design $2 \times 2$ factorial design is the most efficient design to investigate the effects of two or more factors. In this research, the effect of using discovery learning model and vocabulary of environmental field on writing skill of observation report.

The population of this study is all students of class VII SMP Negeri 31 Padang registered in the academic year 2017/2018. Grade VII students of SMP Negeri 31 Padang are spread into eight classes with 248 people. The research instrument is based on existing theory and adapted to the indicators that support this research. Data analysis aims to test the hypothesis proposed in this study. From the data obtained then analyzed the data by testing the hypothesis about the average of the sample study class. The collected data is analyzed through the following steps. The technique of questionnaire analysis is done by analyzing the objective test and analyzing the performance test data. Furthermore, data analysis of the results of this study using statistical methods (test of normality, homegensity, and hypothesis) to see the skills of writing text reports of observations of students of class VII SMP Negeri 31 Padang.

\section{Result}

1. Writing Skills Observation Report of Students, Taught by Discovery Learning Model and Conventional Model

The result of the first hypothesis testing shows that the overall result of the writing text skill of the observation result using the discovery learning model is higher than the writing skill of the student observation report using the conventional model. The value obtained by the students in the experimental class is higher than the value obtained by the students in the control class. Minimum Exhaustiveness Criteria (KKM) for the skills of writing exposition text is 75 . In the experimental class is taught discovery learning model learning there are $80 \%$ of students complete and $20 \%$ unfinished. This is because students learn to use discovery learning model. In the 
experimental class students are taught using the discovery learning model. The discovery learning model has six learning steps according to Shah's opinion (2013: 64). In the experimental classroom study, it is seen that the students are active and understand the text material of the observation report so that the value of the text of the observation report is higher than the control class. In the experimental class, the writing skill of the observation report increased because students were given treatment using discovery learning model.

In the control class students are taught using a conventional model. The conventional model in practice uses one-way communication, the teacher gives explanations or convey the learning materials to the students orally (lecture). Teachers too dominate the learning process, while students are less active because they only listen and record (Djafar in Moses, 2001: 86). The theory is correct because learning by using conventional models can't increase the value of text writing skills reports of student observation results. For learning using conventional models, teachers often spend time explaining the material contained in a book. This resulted in the students not having much time in performing their own activities to understand the information of the teaching materials and doing the exercises in the classroom. At the time of concept discovery, all teaching activities were initiated by the teacher. Finally, students are expected to accept what teachers reject. Teaching explanations are implemented thoroughly, all students are considered equal and individual differences are under-paid by the teacher. As a result, the value of writing skill report skill result of student observation is low. Minimum Exhaustiveness Criteria (KKM) for writing skill of observation report report is 75 , in control class there are $50 \%$ complete student and $50 \%$ student unfinished.

It can be concluded that the theory contained in chapter two and used in this study is true. In the experimental class showed that the value of text writing skill of the observation result of students increased. It refers to the theory used. In the control class the value of text writing skills of the observational reports of students did not increase and the value of the control class was lower than that of the students in the experimental class. The theory used and listed in chapter two is true.

2. Writing Skills Text Reports Observation Results Students Who Have High Vocabulary Mastery Taught with Discovery Learning Models and Conventional Models

The result of the second hypothesis test shows that the skill of writing the text of the observation result of the students who have high vocabulary mastery taught using discovery learning model is higher than the ability to write the text of the student observation result with high vocabulary mastery taught using the conventional model. The value obtained by the students in the experimental class is higher than the value obtained by the students in the control class. Learning using discovery learning model, students are transposed to think critically and actively, and can solve problems encountered. It is suitable for students who have high vocabulary mastery In accordance with the opinion Suryosubroto (2002: 178) that teaching with the model of discovery learning is one model of active learning (activelearning) which in its implementation involves many students

The scores obtained in the experimental class are in terms of content higher than the control class. The score in the experimental class is 3 whereas in the control class it gets score 1 . That means that the Shah theory (2013: 64) is true. That is, this theory is very suitable to be used in this research. Likewise with the control class, in learning students only hear and record the material being taught. It resulted in the learning becomes monotonous and the students are not active in learning in accordance with the opinion of Djafar (2001: 86). With the mastery of the vocabulary of students, the students will have insight that is able to analyze the questions thrown at him and must be answered based on knowledge through the activities of the discussion that he has done. In addition, students will have vocabulary treasuries and sentences that are many and ready to be written into a text text of the observation report. 
3. Writing Text Skills Observation Reports Students with Low Vocabulary Mastery Taught with Discovery Learning Models and Conventional Models

The result of the third hypothesis test shows that the writing skill of the student observation report has low vocabulary mastery taught by using discovery learning model higher than students having low vocabulary mastery taught by conventional model. The value obtained by the students in the experimental class is higher than the value obtained by the students in the control class. In learning the skills of writing the text of the observation result report the students have a low vocabulary mastery taught using a higher discovery learning model than students having low vocabulary mastery taught using conventional models. However, although both have low vocabulary mastery, the value of the text writing skill of the observation report in the experimental class remains high than the control class. This is also due to the influence of discovery learning model treatment applied to the experimental class.

This is because the vocabulary mastery indirectly skill students in making the text of the observation report. However, forming students to have efficient vocabulary mastery does take a relatively long time. In addition to time, desire and willpower are indispensable. Factor of desire and willingness must also be strengthened by the talent that arises from within and outside the student self. This opinion is supported by a statement that is in line with Tarigan's (1989: 3) opinion that the importance of learning vocabulary for learners in language teaching is the quality and quantity and depth of a person. Through the vocabulary can see the development of vocabulary which is the basic educational goal for every school or college. Among the theories used in chapter two with the research done is in line. That is, the theory used in research is correct because in accordance with the results of research that the ability to express the argument in writing can produce text texts reports the results of good observation.

The benefits of improving vocabulary mastery to improve the skill of writing the observational report text. In the study of high vocabulary mastery possessed by students can increase the value of text writing skills reports of student observation results. This is justified by the opinion of Tarigan (1989: 3). Thus, mastery of vocabulary can serve sdapat facilitate a person in expressing his ideas, both orally and in writing in his life and the driving or driving the learning activities so that learning objectives can be achieved. All these benefits and functions greatly assist students in improving the writing skills of the observational report text.

4. Interaction between Vocabulary Mastery of Environment and Model of Discovery Learning in Influencing Writing Text Skill of Observation Result Report

Interaction occurs when the effects of one factor depend on the other factor in influencing something, this is in accordance with the opinion of Shah (2013: 76). This means that each factor between the discovery learning model and the mastery of the vocabulary is allegedly interrelated with each other in influencing the writing skills of the student observation report. The process of interaction between these variables can be explained as follows. Results of two-way anova calculations for testing the fourth hypothesis can be concluded that there is no interaction between the discovery learning model with the mastery of the vocabulary of the environment in influencing the skill of writing the text of the observation report. As has been pointed out earlier that interaction is the effect of the treatment of certain learning models to groups of students who have a certain vocabulary mastery.

However, vocabulary mastery may not necessarily determine success in the skill of writing the observational report text. Many factors as a support, such as intelligence, talent, and others. In addition, teacher readiness factor in using discovery learning model in the process of learning to write text report of observation result also will influence to skill of writing text report of result of observation. There is no interaction so it can be concluded that each factor of the discovery learning model and the mastery of the vocabulary of the environment are not mutually dependent on each other in influencing the learning outcomes of text writing skills of the experimental class 
report and control class. However, the discovery learning model appears to be more effectively applied to both levels of vocabulary mastery of the environment. In other words, the discovery learning model can be applied to students who have high vocabulary in the field of environment and can also be applied to students who have low vocabulary in the field of environment.

\section{Conclusions}

Based on the description, analysis, and discussion of research data that has been done, it can be concluded discovery learning model affect the results of learning to write text reports of observations. First, the result of the test of writing skill of the observation result taught by the discovery learning model is higher than the students taught using the conventional model. Second, the results of students' writing skill tests that have high vocabulary mastery in the field of higher living environment taught by discovery learning models are higher than those with high vocabulary mastery subjects taught by conventional models.

Third, the results of students' writing skill tests that have low vocabulary mastery of the environment are taught with higher discovery learning models than those with low vocabulary mastery subjects taught by conventional models. Fourth, there is no interaction between the discovery learning model and the mastery of the vocabulary of the environment in influencing the skill of writing the text of the observation result of the students of class VII of SMP Negeri 31 Padang.

\section{Acknowledgments}

In the implementation of research and preparation of this article, the authors get a lot of help and guidance from various parties. On this occasion the author would like to thank sincerely to: Prof. Dr. Harris Effendi Thahar, M.Pd As Advisor I and Dr. Irfani Basri, M.Pd As Advisor II, and Mr and Mrs Examiner: Prof. Syahrul, R.,M.Pd, MA, Dr. Abdurahman, M.Pd, and Dr. Yahya, M.Pd.

\section{Reference}

Anggraini, R. (2015). "Pengaruh Discovery Learning Model dan Kebiasaan Membaca terhadap Keterampilan Menulis Teks Eksposisi Siswa Kelas X SMA Negeri 1 Pariaman". Tesis. Padang: Program Studi Teknologi Pendidikan Program Pascasarjana UNP.

Arikunto, S. (2008). Prosedur Penelitian: Suatu Pendekatan Praktek Edisi Revisi V. Jakarta: Rineka Cipta. Atmazaki. (2013). Penilaian Alternatif. Padang. UNP Press.

Balim, A. G. (2009). The Effects of Discovery Learning on Students' Success and Inquiry Learning Skills. Eurasian Journal of Educational Research 35, 1-20.

Cullinant, B. E. (2000). "Independent Reading and School Achievement". Research Journal of the American Association of Scool Librarians. Volume 3, 2000.

Darmawati, U. (2014). Ensiklopedi Bahasa dan Sastra Indonesia Ragam Teks. Klaten: Intan Pariwara.

Dina, P. (2014). "Pengaruh Model Pembelajaran Kooperatif Tipe Cire dan Kebiasaan Membaca terhadap Keterampilan Menulis Resensi Siswa SMP Negeri 6 Merangin Provinsi Jambi". Tesis. Program Pascasarjan UNP.

Djafar, T. Z. (2001). Kontribusi Strategi Pembelajaran terhadap Hasil Belajar. Padang: FIP UNP.

Eko, W. 2015. Penerapan discovery learning dalam pembelajaran ipa sebagai

upaya untuk meningkatkan hasil belajar siswa kelas ix-i Di smp negeri 1

kalianget : Jurnal lensa. Volume 5 Jilid 1 Mei 2015

Hary. (2012). "Pengaruh Model Discovery Learning dan Kebiasaan Membaca Terhadap Keterampilan

Menulis Teks Eksposisi Kelas X SMA Negeri 6 Padang". Tesis. Program Pascasarjana UNP.

Istarani. (2012). Kumpulan 40 Model Pembelajaran. Medan: Media Persada. 
Johari, A. Tom, A.A., dkk. (2013). "Student's Reading Practices and Environments Indonesia". Journal of Applied Linguistics. Vol 3(1), 17-28. Diakses 6 Oktober 2016.

Kantaria, M.N. (2014). A Survey on the Reading Interest of Pre-Service Teachers In Relation To Some Variables. International Research: Journal of Library \& Information Science 4 (1), 96-103.

Kemendikbud. (2013). Bahasa Indonesia Ekspresi Diri dan Akademik untuk SMP/MTsN Kelas.(Buku Guru).Jakarta: Kementrian Pendidikan dan Kebudayaan.

Kemendikbud. (2013). Bahasa Indonesia Ekspresi Diri dan Akademik untuk SMP/MTsN Kelas.(Buku Siswa). Jakarta: Kementrian Pendidikan dan Kebudayaan.

Kosasih, E. (2013). Cerdas Berbahasa Indonesia untuk SMP/MTsN kelas VII (Kelompok wajib).Jakarta: Erlangga.

Lara, S. 2017. Pengaruh model pembelajaran discovery learning terhadap keterampilan menulis teks laporan hasil observasi Siswa kelas $x$ sma negeri 1 enam lingkung Kabupaten padang pariaman. Jurnal. Di akses tanggal 2 januari 2018

Nawarathne, I.M. (2012). Reading Interest of Undergraduates in Sri Lanka. International Refereed Research Journal 3 (1), 196-203.

Oktaviani, P. (2015). "Model Discovery Learning dalam Keterampilan Menulis Teks Eksposisi dan Berpikir Kritis". Jurnal Penelitian Pendidikan, diakses 20 Oktober 2016.

Priyatni, E. T. (2014). Desain Pembelajaran Bahasa Indonesia Dalam Kurikulum 2013. Jakarta: PT Bumi Aksara.

Riduwan. (2005). Belajar Mudah Penelitian Anak untuk Guru, Karyawan, dan Penelitian Pemula: Bandung: Alfabeta.

Roestiyah. (2008). Strategi Belajar Mengajar. Jakarta: Rineka Cipta.

Rohimah, I. (2014). BUPENA Buku Penilaian Otentik Bahasa Indonesia. Jakarta: Erlangga.

Rumijati. 2015. Pengaruh Model Pembelajaran Penemuan Terhadap Motivasi

dan Prestasi Belajar Memahami Teks. Jurnal.Volume 1 No 2 April 2015.

Sanjaya, W. (2006). Strategi Pembelajaran Berorientasi Standar Proses Pendidikan. Jakarta: Perdana Media.

Saputra, A., dkk. (2016). Penerapan discovery learning menggunakan reflika untuk Meningkatkan berpikir kritis dan sikap nasionalisme. Jurnal Studi Sosial Vol 4, No 1 (2016)

Septriyanti, Y.,dkk. (2012). Hubungan penguasaan kosakata Dengan keterampilan menulis argumentasi Siswa kelas $x$ sma negeri 6 padang. Jurnal Pendidikan Bahasa dan Sastra Indonesia, Vol. 1 No. 1 September 2012; Seri E 339-425

Sudjana. (2005). Metoda Statitiska. Bandung: Tarsito.

Sugiyono. (2010). Metode Penelitian Pendidikan. Bandung: Alfabeta.

Suryosubroto, B. (2002). Proses Belajar Mengajar di Sekolah. Jakarta : Rineka Cipta.

Tarigan, HG. (2008). Menulis Sebagai Suatu Keterampilan Berbahasa. Bandung: Angkasa.

Wahono, dkk. (2013). Mahir Berbahasa Indonesia Untuk SMP/MTs kelas VII. Jakarta : Erlangga.

Waluyo, B. (2014). Bahasa dan Sastra Indonesia 1. Solo: PT Tiga Serangkai Pustaka Mandiri. 